\title{
THEMATIC MAPS FOR ELECTRONIC LARGE-SCALE ATLAS OF EXPERIMENTAL FARMS LAND USE
}

\author{
Kovalchuk I., Dr. Geogr., Prof., \\ Bogdanets V., PhD., Assoc. Prof. \\ National University of Life and Environmrntal Scieces of Ukraine, Kyiv \\ E-mail:vb0987@ukr.net
}

The article analyzes process and issues of thematic maps compiling for large-scale electronic atlas of land use of university experimental farms. It shows aspects of the practical use

of mapped information that reflects the parameters of soils and land quality.

Keywords: atlas mapping, GIS mapping, land resources, cartograms, parameters of soil, electronic atlas.

\section{Problem statement.}

The problem of mapping of land resources in Ukraine in the whole territory of rural councils, agricultural enterprises of different types of management and ownership is becomes serious and topical nowadays. Most of planning and cartographic materials of various scales were created at least 15-25 years ago and they are clearly outdated. Therefore, the situation today concerning the status of cartographic mapping and land use within administrative districts and various types of agricultural enterprises is rather complicated. Immediate updating of information on land resources and soil maps acquired great importance. One of the main means of solving this problem is to involve the methods of GIS-mapping of land resources with use of remote sensing data and create comprehensive maps at different scales.

\section{Analysis of recent research and publications.}

The issues of development of general methodology of mapping of natural resources were reviewed by I.Levytskyy, V.Razov, A.Zolovskyy, G.Parkhomenko, L.Rudenko, V.Peresadko, I.Kovalchuk and others. Among leading foreign studies should be noted works by V.S. Tikunov, A.V.Dontsov, F.J. Ormeling, N.Ulugtekin, Xie Chao et al.

The aim of the article - to analyze process and issues of thematic maps compiling for large-scale electronic atlas of land use of university experimental farms, to describe the features of the practical use of map information that reflects parameters of soils. 


\section{Presenting main material.}

Thematic content of maps for the largescale electronic atlas of land cover and land use of university research farms is the main scope of atlas. Maps of different parameters of soil cover, content of nutrients, climatic factors, agricultural crops localization by years of cultivation with combination of remote sensing data as well as application of these maps on agricultural practice are overviewed in the article.

\section{Розташування \\ ВП НУБіП України "Великоснітинське НДГ ім. О. В. Музиченка" у Фастівському районі}

Кафедра геодезії та картографії

Навчально-наукова лабораторія картографічного моделювання проблем природокористування

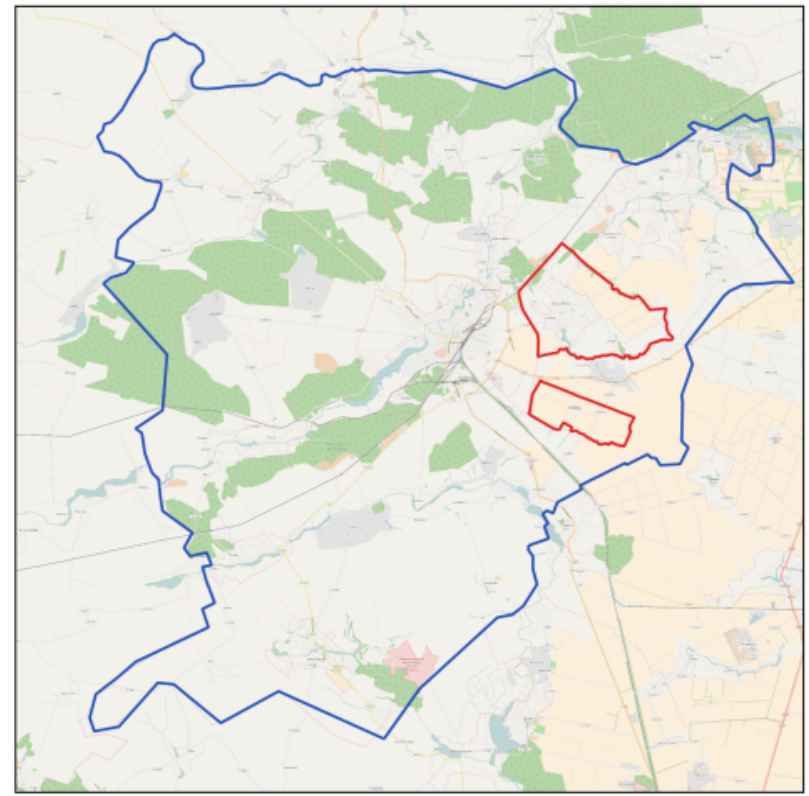

Умовні позначення

- межа району

- межа території НДГ

Використано карти сервісу OSM Mapnik, 2016 p.

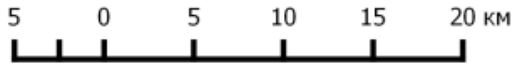

Київ = 2016

Figure 1. The logical-semantic model of development land use planning by the historical and socialist forms. 
To compile maps, QGIS software was used in combination with online map services, accessible via QGIS plugins, along with the Public cadastral map of Ukraine and cadastral documentation supplied by the university land resources management office. Landsat5-7-8 and
Orbview images were used to actualize maps of land use and land parcel borders.

Maps of agricultural crops localization by years of cultivation are useful to control crop rotation and optimal crop placement planning. Maps of organic matter content and hydrolyzible

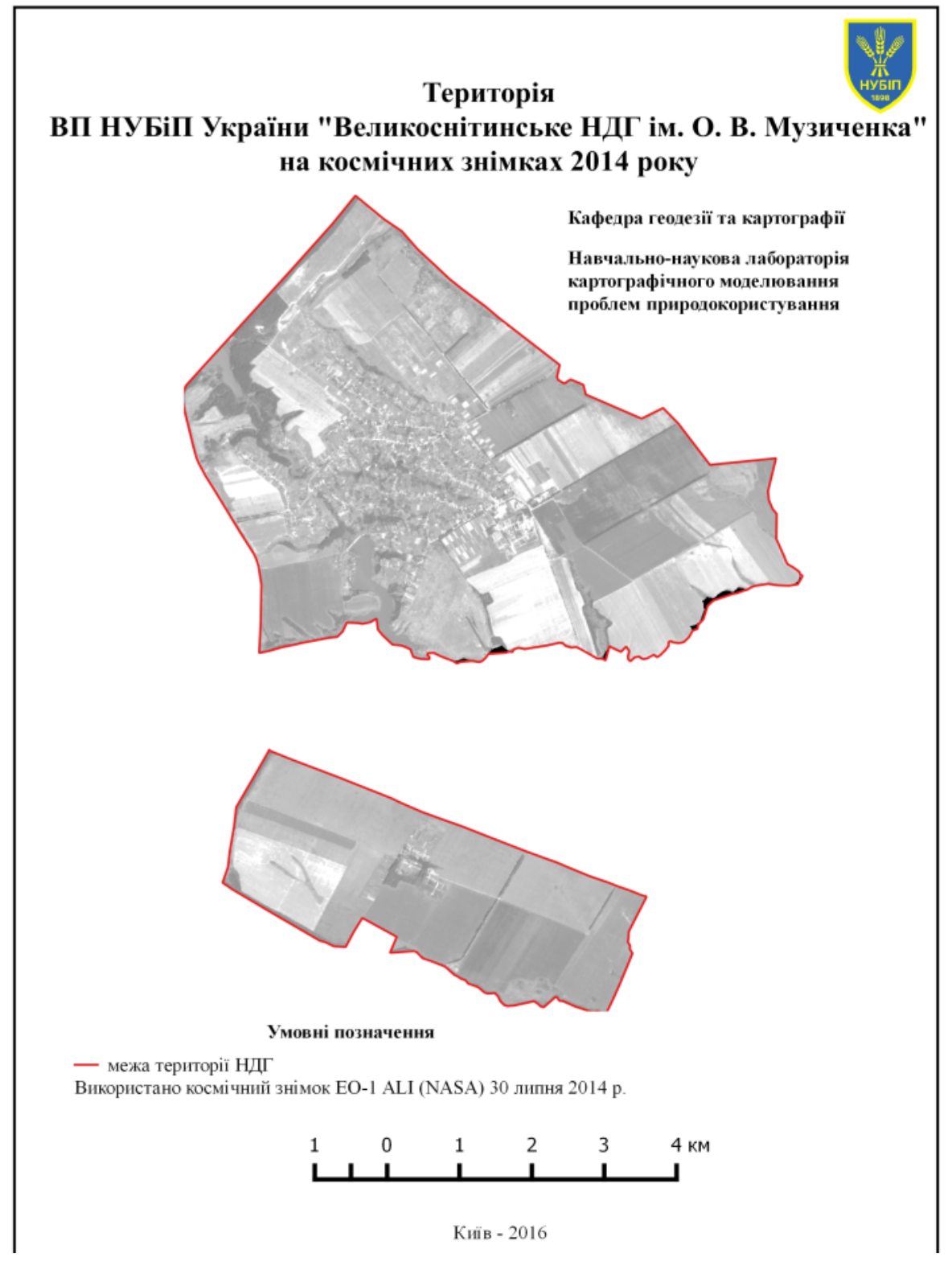

Fig 2. The territory of enterprise shown on satellite images. 

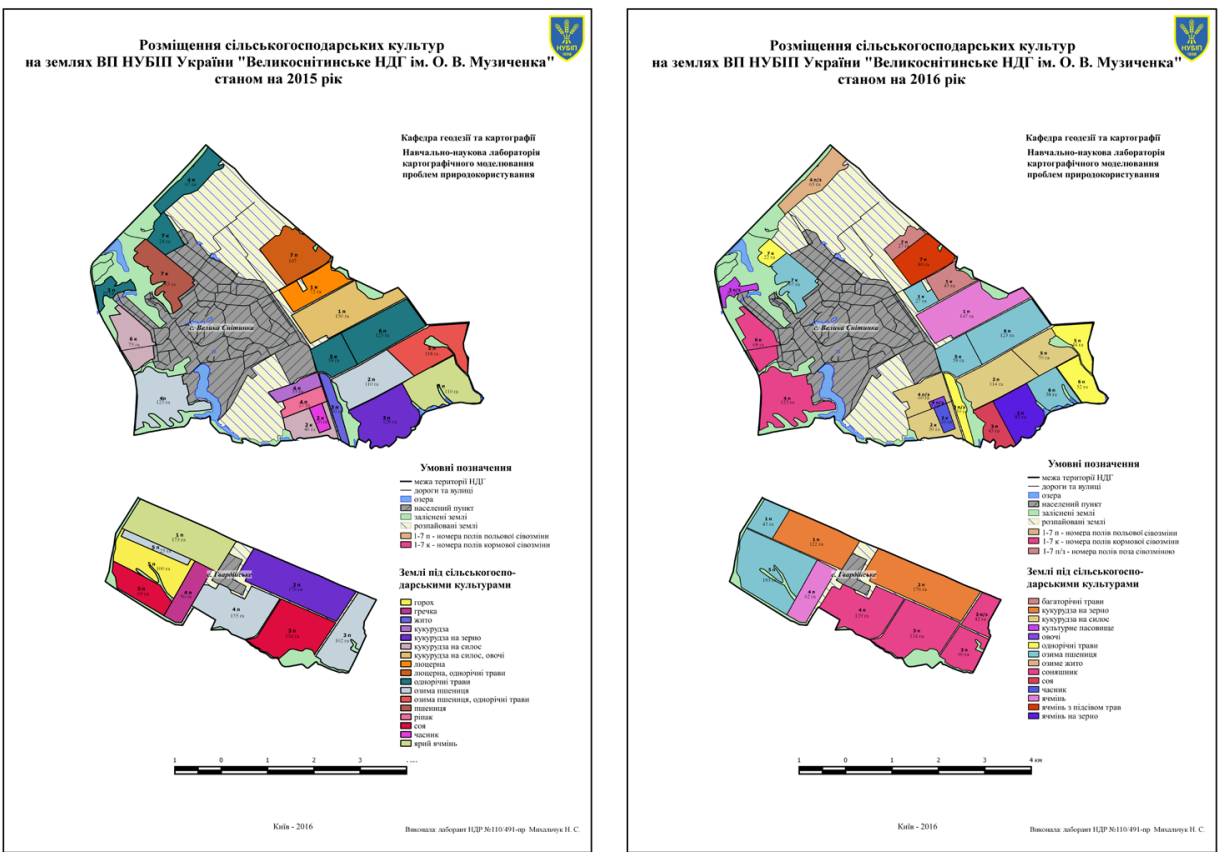

Fig. 3. Maps of crops placement in the fields NDH in 2015 and 2016 respectively.

nitrogen content in soils are of primary interest for agronomists, as well as maps of estimation assessment of nutrients to plants.

Also a group of maps that display content of phosphorus, potassium, copper and other elements, important for crop cultivation, were compiled. Agrophysical properties of soils were subject of the other part of our atlas, using these series of maps, agronomists will be able to assess preferable fields for those crops, which have high requirement to soil air and water regime.

Series of maps of the atlas relate to crop productivity, degradation processes, climate conditions, water-protective measures, etc., will help managers to organize agricultural production process and technological operations.

Main procedures for compiling such kind of maps, stages and approaches to map editing are shown in [1]. The basis for the research is the Scientific-educational laboratory «Cartographic modeling of nature use» at the Department of Geodesy and Cartography, Land Management Faculty, NULES of Ukraine, which is equipped with modern computer and mapping software.

During the field and cameral studies, background, statistical and mapping information was collected, main problems were identified and the prospects of cartographic support of the enterprise were outlined. In addition to mapping software also critical component of the research were published in the literature (monographs, textbooks, articles, etc.) and archives department of geodesy and cartography, as well as materials developed at other departments of NULES and Land Resources service of NULESU. 
Online mapping services available through the modules of QGIS, the data of the Public cadastral map of Ukraine and acts on the ownership of land provided by the Department of Land Resources NUBiP Ukraine, and satellite imagery territory of Landsat, Orbview, Ali, were used. This data is used to specify the boundaries of sites, determining the actual state of land use, etc. (Figure 1-2).

To improve the control of use of agricultural crop rotation, maps of crops placing were compiled (Figure 3). They contain information about the culture

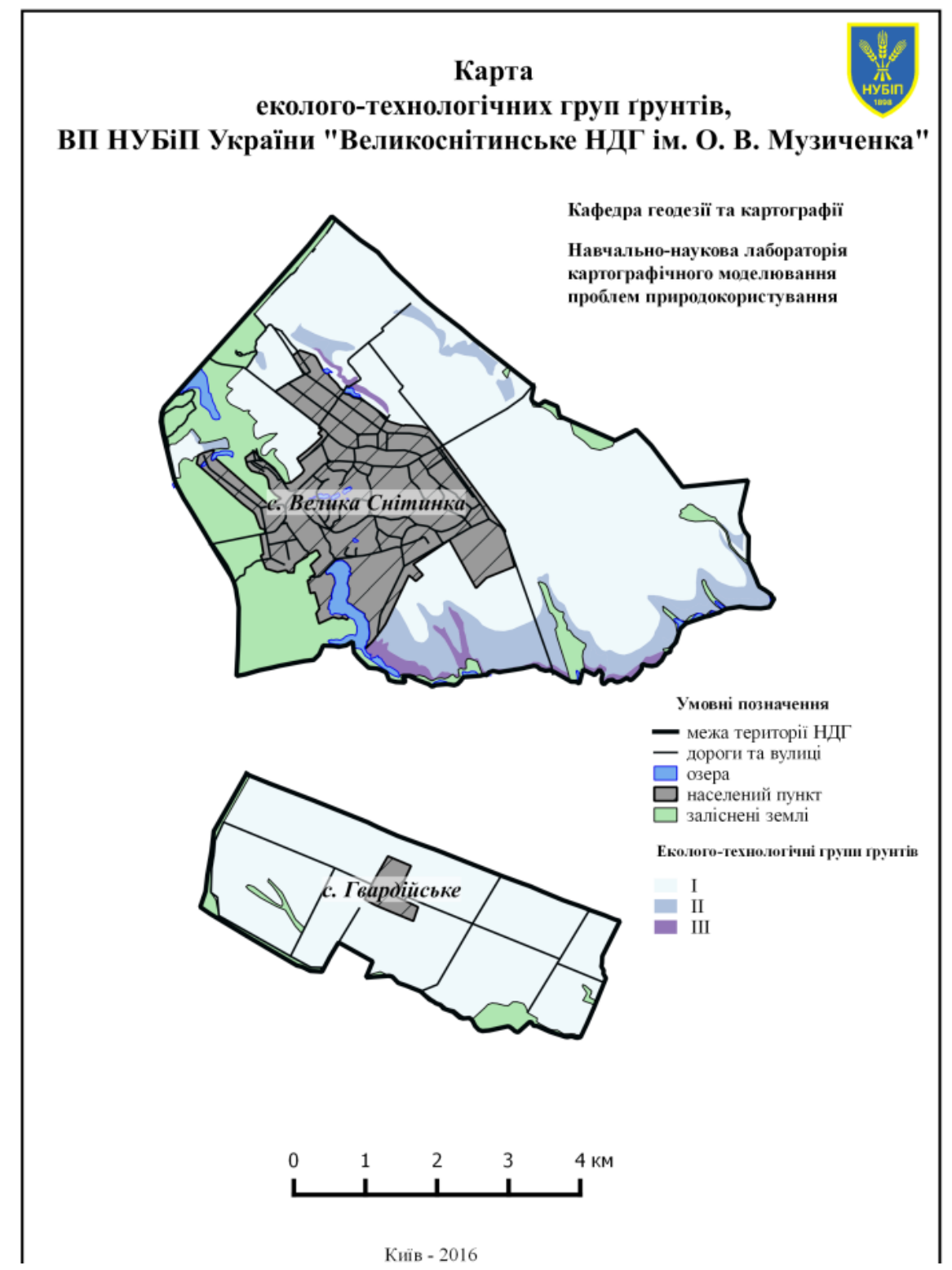

Figure 4. Cartogram of ecological and technological groups of soils. 
grown over the years and can track compliance to crop rotation on crop rotation for years.

Figure 4 represents cartogram of ecological and technological groups of soils containing information on soil cover of agricultural land according to the survey conducted in the late 1990s - early 2000 s on the territory of village councils at Kyiv region. The data indicate the presence of the vast part of the soil with high natural productivity.

Also a series of maps was developed, that describe the performance of content in the soil and the availability of other plant nutrients - phosphorus, potassium, copper and so on. Several maps atlas dedicated display the most important agrophysical properties of soils, characteristics of weather and climate growing crops, because these are the parameters that must be considered primarily in the management of agricultural activities.

\section{Conclusions.}

A series of maps for large-scale electronic atlas of land use was developed, it is dedicated to mapping of soil parameters of the study area, land quality, agrophysical and agrochemical indicators and placement of crops. In the process of map compilation a dialogue with employees of the enterprise was provided, archival materials were widely used in conjunction with current satellite images of the study area. Atlas and its individual components will be used as a tool to implement monitoring studies of soil, determine the level of contamination, evaluating the degree of destruction of land erosion and other geomorphological processes and intensity of degradation phenomena on agricultural land. This large-scale electronic atlas and state land resources will act as an agronomist working tool for planning and tracking crop rotation, complex development of soil and water conservation measures, control yield of crops grown, application of mineral and organic fertilizers and so on. The developed atlas will serve as information and analytical base for monitoring and management of land resources for development of land conservation measures. Use of the atlas in educational farms involves the interaction with the user for input and output data, mapping related information, including to plan manufacturing operations.

\section{References}

1. Bogdanets V. Algorithm for compiling of large scale electronic atlas for land-use and land resources management / V. Bogdanets // 1st International Scientific Conference «WaterLand-2016» 06-12 June, 2016, Lithuania, Kaunas. - P.8-10.

2. Bogdanets V.A. Electronic atlases: past and present / VA Bogdanets, IP Kovalchuk // Chasopys kartografii. - 2014 - Vol. 11. - P. 194-215.

3. Kovalchuk IP Topical Issues of atlas mapping and state of land use of administrative district / IP Kovalchuk T. levsiukov, OV Vakulenko, NM Lishchuk, VP Skavronskyy, I. Tarasova // Agrokhimiya ta gruntoznavstvo. - Issue 77 - 2012 - P.14-18.

4. Kraak, Menno-Jan; Ormeling, Ferjan. Cartography: visualization of spatial data / M. J. Kraak, F. Ormeling. - Guilford Press, 2003.

5. Rudenko LG Kartohrafycheskoe issledovanie prirody / L.H.Rudenko, GA Parkhomenko, A.M.Molochko et al. - Kiev: Naukova dumka, 1991. $-212 \mathrm{p}$.

6. Uluğtekin, N. A new low-cost approach to national statistical electronic atlas. / N.Uluğtekin, i..ö. Bildirici. // Third Turkish-German Joint Geodetic Days, volume II, 579-588. Istanbul 1999. Access: http://www. iobildirici.com/ papers / papers / 14.pdf 
7. Wang Y., Su Y., Chen X. et al. Visualization issues in the development of electronic atlas in China / Journal of Geographical sciences, 15, 1, 2005. 87-96 pp.

8. Xie Chao, Chen Yu-fen. Realization of Multimedia Electronic Atlas Based on Flash Technique Hydrographic Surveying and Charting. 2005-04 Access: http://en.cnki.com.cn/Article_en/CJFDTOTAL-HYCH200504018.htm

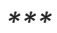

Ковальчук І.П., Богданець В.А. ТЕМАТИЧНІ КАРТИ ВИКОРИСТАННЯ ЗЕМЕЛЬ ЕЛЕКТРОННОГО ВЕЛИКОМАСШТАБНОГО АТЛАСУ НАВЧАЛЬНО-ДОСЛІДНИХ ГОСПОДАРСТВ

у статті аналізуються укладені тематичні карти використання земель для великомаситабного електронного атласу навчально-наукових господарств універcumemу. Також розглянуто аспекти практичного використання відображеної ін- формації, що відбиває параметри грунтів і якості земель.

Ключові слова: атласне картографування, картування ГІС, земельних ресурсів, картограми, параметри грунту, електронний атлас.

Ковальчук И.П., Богданец В.А.

ТЕМАТИЧЕСКИЕ КАРТЫ ИСПОЛЬЗОВАНИЯ ЗЕМЕЛЬ ЭЛЕКТРОННОГО КРУПНОМАСШТАБНОГО АТЛАСА УЧЕБНО-ОПЫТНОГО ХОЗЯЙСТВА

В статье анализируются тематические карты использования земель для крупномасштабного электронного атласа учебно-научных хозяйств университета. Также рассмотрены аспекты практического использования отображаемой информации, отражающей параметры почв и качества земель.

Ключевые слова: атласное картографирование, картирование ГИС, земельных ресурсов, картограммы, параметры почвы, электронный атлас. 